\title{
The prophet like Moses (Dt 18:15-22): Some trajectories in the history of interpretation
}

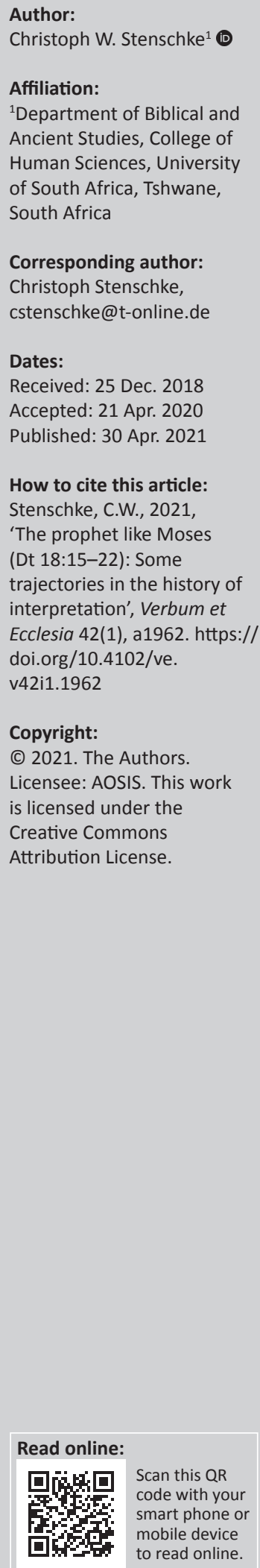

This article traces some of the trajectories of the Deuteronomic announcement of a 'prophet like Moses'. After examining its meaning in the immediate context, the article first traces references to this figure in early Jewish sources. It then examines how Jesus is portrayed as the prophet of Deuteronomy 18 in the Gospels. What is meant when people ask whether Jesus could be the prophet? Would he himself identify with this figure through word and deed? What implications would such an identification have had for his contemporaries? Why does this designation only appear rarely outside of the Gospels? A further trajectory is the quotation of Deuteronomy 18:15,19 in Acts 3:22-23. What is meant by Peter's identification of Jesus as the prophet like Moses? What does Peter link with the acceptance and rejection of this prophet? How has Luke altered the text of Deuteronomy in the application of this prediction to Jesus? The article closes with a summary and suggests implications for the understanding of early Christian rhetoric, of Israel's response and of prophets in today's church and society.

Intradisciplinary and/or interdisciplinary implications: This article is placed within the discipline of biblical studies and Jewish studies (for the reception history in early Judaism). An in-depth study of the reception of the Deuteronomic prophet like Moses in Acts 3, where the prediction is explicitly quoted and declared to be fulfilled in Jesus Christ, reveals how this reference functions for the Christology of Acts, its proclamation of the Gospel and its understanding of Israel. Those revering Moses must now listen to Jesus. To reject Jesus means to forfeit one's membership in the people of God. This challenges studies which do not pay sufficient attention to this claim.

Keywords: Deuteronomy; Moses; prophecy; prophets; Gospels; Acts; Peter.

\section{Introduction}

One of the storm centres of biblical research is the use of the Old Testament in the New Testament. Endless articles, monographs and textbooks have developed the necessary nuanced methodology ${ }^{1}$ and have examined individual passages and whole books of the Old Testament to see how they have been received in the New Testament. This quest is part of a larger turn to the reception history of the Bible (for a survey, see Stenschke 2015). This focus is likely to continue as it opens vast new fields of research.

Scholars have studied the many quotations from the Old Testament, the endless allusions to the Old Testament, the references to events in the Old Testament and the way in which the Old Testament serves as the substructure for individual books or the grand narrative of the New Testament (for a survey, see Beale \& Carson 2007). In this quest, scholars have also focused on the use of the Book of Deuteronomy in the New Testament (one example is Moyise \& Menken 2007; survey of the evidence in Fuhrmann 2013). While the number of quotations from Deuteronomy is limited, there are many allusions and echoes.

Our focus is on the prediction of Moses in Deuteronomy 18 of a prophet like himself, who will be raised up by God:

The Lord your God will raise up for you a prophet like me from among your own people; you shall heed to such a prophet ... I will raise up for them a prophet like you from among their own people; I will put my words in the mouth of the prophet, who shall speak to them everything that I command. Anyone who does not heed the words that the prophet shall speak in my name, I myself will hold accountable. ${ }^{2}$ (Dt 18:15, 18-19) 
How and in what ways does the New Testament draw on this announcement? Allusions to and quotations of this prophecy appear on several occasions in the Gospels. What is meant when people ask whether Jesus could be the prophet? Could he be this particular prophet? Would he himself identify with this figure through word and deed? What implications would such an identification have had for his contemporaries? Why does this designation rarely appear outside of the Gospels? What is meant by Peter's clear identification of Jesus as the prophet like Moses in his speech in Acts 3? What does Peter link with the acceptance of this prophet? How has Luke altered the text of Deuteronomy in the application of this prediction to Jesus?

In order to find some answers, we will first survey the context and significance of this prediction in its Old Testament context, then turn to its reception in Early Judaism and consider possible references to this prophet in the Gospels. Our emphasis will be on Acts 3. A closing section summarises the reception of this passage from Deuteronomy and discusses some implications.

\section{The prophet like Moses in the context of Deuteronomy 18:15-22}

The prediction of a prophet like Moses appears in the extended farewell discourse of Moses in Deuteronomy (for a summary of the themes of Dt, see Olson 2013). Moses looks ahead to the time after his own death. In the larger context of instruction regarding leaders and authorities in Deuteronomy 16:18-18:22, ${ }^{3}$ the people are assured: when Moses will be gone, God will provide other prophets to convey his word. The immediate context is that of a strong warning against the mantic practices of the nations whose land Israel is about to enter. ${ }^{4}$ Those nations practice divination: they have their soothsayers, augurs or sorcerers (for the terminology, see Otto 2016:1484-1485). They cast spells or consult ghosts or spirits and seek oracles from the dead (Dt 18:10-11). People who practice these things are abhorrent to the Lord:

It is because of such abhorrent practices that the Lord your God is driving them out before you. You must remain completely loyal to the Lord your God. Although these nations ... do give heed to soothsayers and diviners, as for you, the Lord your God does not permit you to do so. (Dt 18:12-14)

In addition to the prohibition of pagan practices, there will be no need to turn to other sources. The people of Israel not only have the written law (of Moses), but will also have the living voice of prophecy. ${ }^{5}$ After Moses there will be others from among the Israelites who can inquire of the living God and mediate his word to the people: 'I will put my words in the mouth of the prophet, who shall speak to them everything

3.Olson (2013:655) and others (for instance, S. Kaufman and G. Braulik) have pointed out that the sequence of topics in the law code in Deuteronomy 16-26 roughly follows the pattern of the Ten Commandments.

4.This context is rightly emphasised by Chianeque and Ngewa (2006:235): 'Whereas the Canaanites used a range of techniques in attempts to determine or manipulate the will of the gods, Yahweh acknowledged only one way to hear from him. That way was through the words of a prophet'. For a detailed treatment, see Römer (2009).

5.The people are not referred simply to the written Law of Moses but are promised prophets; see the discussion below and in detail in Otto $(2016,2017)$. that I command' (Dt 18:18); there is no other legitimate channel of revelation. Therefore, it is mandatory that the people of Israel listen to this prophet/these prophets. Those who refuse (and seek revelation elsewhere) will be held accountable. ${ }^{6}$

The following verses (Dt 18:20-22) forbid speaking in the name of other gods or presuming to speak in God's name without having been commissioned to do so. In addition, criteria are provided for recognising words that the LORD has not spoken (Dt 18:21-22; for detailed treatment, see Christensen 2001:398-413).

According to Deuteronomy 18:16-17, the people were afraid of further direct communication with God ('if I hear the voice of the LORD my God any more, or ever again see this great fire, I will die'). As their fear is legitimate, henceforth God will communicate with the people through Moses and prophets like Moses. ${ }^{7}$ Many books of the Old Testament refer to men and women speaking in God's name to individual Israelites, groups or the whole people, although they are hardly ever identified as in the tradition of Moses or as acting in fulfilment of the prediction in Deuteronomy 18 (for prophecy and its significance in the Old Testament, see Barton 1992; Schmitt 1992). There are several accounts of instances when those who refused to listen to the prophets eventually came under divine judgement as foretold by Deuteronomy 18.

The tension between Moses as the giver and embodiment of the Law (throughout Exodus to Deuteronomy), which regulates all aspects of life, and the charge to pay heed to a future prophet/prophets is part of the complex blend of polarities and tensions in the theology of Deuteronomy (for a survey, see Olson 2013:657). The recurring emphasis in Deuteronomy on hearing Moses' words as applying to 'today' (hayyôm, occurring 56 times in the book) might suggest that at the time of writing, prophets (Moses is presented as a prophet: 'a prophet like me') played a role in applying the Law to particular instances or even future developments (see below).

The reconstruction of the history of composition of Deuteronomy in critical scholarship sheds further light on the announcement of a prophet or of prophets like Moses (for a survey, see Olson 2013:655-657; for a detailed history of critical research, see Otto 2012:62-230), although it is difficult to determine from which stage in the development onwards the announcement was part of the traditions behind the book or the book itself. In his recent magisterial commentary on Deuteronomy, Eckart Otto (2016:1494-1503) has identified in the law concerning prophets in Deuteronomy 18:9-22 traces of

6.According to 1 Samuel 28:17-19, King Saul was killed because he failed to obey the voice of YHWH as delivered through the prophet Samuel. The reception of Deuteronomy 18 in Acts 3 makes these implications explicit.

7.Marshall (2007:548) writes that although Moses himself will not be there, the people 'will know what to do because God will raise up for them a prophet similar to Moses to act as intermediary between God and them. Since the people were fearful of direct communication with God, God promised that he would raise up one fearful of direct communication with God, God promised that he would raise up one
from among them to act as prophet and that he would put his own words into the mouth'. 
a Deuteronomistic redaction of earlier traditions, of a postexilic continuation ('Fortschreibung') and of a Deuteronomistic redaction related to $\mathrm{Mt}$. Horeb which led to the inclusion of the prophet like Moses tradition into Deuteronomy ${ }^{8}$ (Otto 2016):

In Dtn 18,15 nehmen nach der Absage an die nicht von JHWH gegebene und also nicht autorisierte Divination wieder die Autoren des deuteronomistischen Deuteronomiums den Griffel auf mit der deuteronomistischen Verheißung einer mosaischen Prophetie. (p. 1497)

The origin or inclusion of the announcement of Deuteronomy 18 is conceivable at various stages in the prehistory of the canonical text of Deuteronomy. Olson (2013) notes that:

[ $t$ ] he traditions behind Deuteronomy likely had their beginnings in northern Israel, given the thematic parallels with the northern prophet Hosea and northern place names in Deut 11:29-30; 27:11-13 ... These Deuteronomic tradents eventually migrated south to Judah after the Assyrian conquest of the North in 722 BCE. (p. 655)

In this reconstruction (see Cook 2004), the reference to the prophet like Moses (if part of the early traditions which eventually became part of canonical Dt) might have served to bolster the status and claims of prophets with reference to the authority of Moses.

There is consensus in critical scholarship that Deuteronomy or an early form of it emerged in association 'with the discovery of the book of the law as part of religious reforms in the Jerusalem temple conducted by King Josiah in $621 \mathrm{BCE}$ (2 Ki 22:8,11)' (Olson 2013:655-656). Accordingly, some parts of Deuteronomy (primarily Dt 28) were modelled after 7thcentury neo-Assyrian vassal treaties or loyalty oaths with the aim of replacing loyalty to the Assyrian king with exclusive loyalty to the God of Israel (Olson 2013:656). In this context, the announcement of a prophet or prophets like Moses might have functioned to validate and authorise prophets of the southern kingdom and to delegitimise other leaders and authorities, whether within the community or associated with the Assyrians or other nations.

In a likely first round of redaction during the exile (587-539 BCE), (Olson 2013) this material:

$[w]$ as expanded and attached as an introduction to the so-called Deuteronomistic History of Joshua-Judges-Samuel-Kings. This exilic version of Deuteronomy provided an explanation for Israeli defeat by the Babylonians (2Kgs 25) and the loss of Israel's land (the exile as God's punishment for disloyalty). The book also offered a polity or communal structure to guide Israel's reconstitution of itself as an obedient community under YHWH once the exiles returned back to the land. ... The Decalogue in Deut 5 came to function as a table of contents for the laws that followed in Deut 12-26 ... (p. 656)

Also in this context the origin or inclusion of the announcement of a prophet or prophets like Moses is conceivable: the people's refusal to heed to the prophets (as announced by

8.For the overall assessment of the literary history of Deuteronomy, see Otto (2012:231-256). According to Otto (2012:274-280) in its canonical form (2012:231-256). According to Otto (2012:274-280), in its canonical form,
Deuteronomy is a prophetic testament/will in which Moses is cast as an 'Urbild' of prophecy.
Moses) contributed to the catastrophe. Now during the exile and once back in the land, a repetition of this pattern must be avoided at all cost and be replaced by new obedience: the people are to heed to present and future prophets (some active during the exile itself) and not to the dominant religious discourse in their places of exile or what they are likely to encounter in the land upon their return (see Otto 2016:1497). According to Otto (2016):

Die Mosaizität dient der Legitimation der Prophetie, womit die Frage nach der Abgrenzung wahrer von falscher Prophetie, die sich im 6. Jahrhundert verschärft stellt, beantwortet werden soll. ... Die in der Erzählzeit angesichts der neubabylonischen Krise aufgebrochene Frage nach der Legitimität von Prophetie wird in Dtn 18,16-18 so beantwortet, dass ausgehend von der Charakterisierung der von JHWH eingesetzten Prophetie als mosaisch ihre Einsetzung unter den Schild der von JHWH am Horeb gesprochenen Einsetzungsworte gestellt wird. (p. 1497)

A similar function would apply to the situation of the Jewish exiles who returned from Babylon in the Persian period after 539 BCE, when their exilic version of Deuteronomy probably underwent further editing (for a survey, see Olson 2013:656). According to Olson (2013:656), 'additions likely included the more developed monotheism of Deut 4 and the increased concern about separation from other nations and purity (7; 9:1-6; 12:2-7; 14:1-20; 23:1-9)'. Both concerns would be supported by the announcement of Deuteronomy 18: a prophet or prophets can provide guidance in this regard and must be heeded.

The declaration in Deuteronomy 34:10-12 of Moses' uniqueness whose authority would never be surpassed probably provided a Persian-period closure to the book of Deuteronomy 34:

Never since has there arisen a prophet in Israel like Moses, whom the Lord knew face to face. He was unequalled for all the signs and wonders that the Lord sent him to perform in the land of Egypt, against Pharaoh and all his servants and his entire land, and for all the mighty deeds and all the terrifying displays of power that Moses performed in the sight of all Israel. (vv. 10-12)

This assertion separates Deuteronomy 'in a definitive way from the books of the "former prophets" that followed in Joshua-2 Kings' (Olson 2013:656; see Otto 2017:2272-2277 for the history of research on Dt 34). ${ }^{9}$ It questions the role and importance of a prophet or prophets during the Persian period: all prophets after Moses did not reach his status and will not. They did and do not enjoy the unique intimacy with God which characterised Moses and which legitimised his authority. ${ }^{10}$ Neither did they nor do they perform the miracles

9.0tto (2017:2284) suggests: 'Mit dem Epitaph Dtn 34:10-12 schließt die nachexilische Fortschreibung in Gestalt der Pentateuchredaktion die Integration des Buches Deuteronomium in den Pentateuch und damit den Pentateuch insgesamt ab'.

10.0tto (2017: 2285) notes 'Mit der Formulierung in Dtn 34:10, JHWH habe Mose 'von Angesicht zu Angesicht' ... gekannt, wird wie in Dtn 31:14-15.23 auf Ex 33:11 Bezug genommen, so wie in Dtn 34:11 an die Exodusüberlieferung angeknüpft wird. Das Reden von der Begegnung mit JHWH 'von Angesicht zu Angesicht' ist nach dem Bundesbruch in Ex 32 ein Mose allein eingeräumtes Privileg, das mit seinem Tod, sobald die verschriftete Tora die Funktion der Offenbarungsmittlerschaft übernimmt, endet und nicht auf die nachmosaische Prophetie übergehen kann. Dtn 34:10-12 intendiert gerade nicht eine Aufwertung der nachmosaischen Prophetie des Corpus propheticum, sondern die Unterordnung der Prophetie unter die Tora. Es geht um den Widerspruch nachexilischer priesterlicher Kreise gegen 
which are ascribed to Moses. While Deuteronomy 18 announces a prophet or prophets like Moses (and thus relativizes his special role and legitimises their roles), Deuteronomy 34 underscores the uniqueness of Moses. Otto (2017) comments:

In Dtn 34:10 wird Mose als Erzprophet grundsätzlich von jeder Form nichtmosaischer, also nicht an die Tora gebundener Prophetie abgegrenzt. Um dieser Abgrenzung willen wird die deuteronomistische Prophetentheorie in Dtn 18:9,14-20 korrigiert. ... Mit dem Tod des Erzpropheten Mose endet die Zeit mosaischer Offenbarungsmittlerschaft der Tora. Von da an ist die Toraoffenbarung nur noch in der von Mose verschriftlichten Gestalt zugänglich und Prophetie an die Auslegung der Tora gebunden. Die Autoren der nachexilischen Fortschreibung des Deuteronomiums wenden sich im Epitaph in Dtn 34:10-12 mit der Theorie des Erzpropheten Mose gegen eine nachexilische Tradentenprophetie, wie sie sich insbesondere im Buch Jeremia niedergeschlagen hat. ${ }^{11}$ (p. 2284)

Some of the tension might be due to different emphases. In Deuteronomy 34, the focus is not on Moses' words (which constitute the main content of Deuteronomy; in Deuteronomy 18 and its wider context, Moses speaks as a law giver) or the words of prophets in his wake (not in view), but on the various miraculous deeds performed by him since his return to Egypt in Exodus up to the present.

Our survey of the history of composition of Deuteronomy in critical scholarship shows that several stages in the development of the canonical text can be reconstructed. The origin or inclusion of the tradition of the Deuteronomic prophet like Moses is conceivable in one or several of these different stages and would have served the contemporary concerns of the tradents or redactors well. Thus, the text of Deuteronomy 18 not only led to a rich history of reception (a fraction of which is traced here) but can in itself be understood as the product of redaction and reception processes of earlier traditions.

\section{The prophet like Moses in early Judaism ${ }^{12}$}

The prediction of a prophet like Moses - in its original context not meant as a prediction of an eschatological prophetic figure - came to be understood as such in the 1st century BC and AD. Deuteronomy 18:15, 18-19 was understood as referring to an eschatological prophetic figure. For example, several texts from Qumran cite Deuteronomy 18 in this respect and predict a prophet. 4QTestimonia (175) I, 5-8 cites Deuteronomy 18:18-19 without further comment. 1QS IX speaks of a coming prophet:

\footnotetext{
(footnote 10 continues...)

solche der Prophetie, die sich auf eine nachmosaische Offenbarungsprophetie unabhängig von Mose berufen. Der Bucherzähler spricht nach Dtn 34:6b in Dtn 34:10-12 mit dieser Abgrenzung von der nachexilischen Tradentenprophetie im Corpus propheticum die Adressaten des Deuteronomiums der nachexilischen Erzählzeit unmittelbar an'.

11.Otto notes that 'Alle Propheten nach inm werden auf die Tora als Quelle des Gotteswillens verwiesen und sollen Prediger der Tora sein, denen die Tora mosaische Autorität verleiht und sie zu 'Propheten' wie Mose werden lässt'.

12.For surveys, see Aune $(1983,2010)$ and Steyn (1995:141-142); for a survey of the history of the period, see Seeman and Marshak (2010). Lim (2007) and Crawford (2013) provide overviews of the reception of Deuteronomy in early Judaism. While prophets are mentioned (that is, warnings against false prophets, cols. 54 and 61) prophets are mentioned (that is, warnings against false prophets, cols. 54 and 61)
in the paraphrase of Deuteronomy 12-28 in the Temple Scroll (11Q19, cols. 51-66), in the paraphrase of Deuteronomy 12-28
the prophet like Moses does not appear.
}

They should not depart from any counsel of the law in order to walk in complete stubbornness of their heart, but instead shall be ruled by the first directives which the men of the Community began to be taught until the prophet comes, and the Messiahs of Aaron and Israel. ${ }^{13}$ (cols. 10-11)

This is followed by the (in view of the coming prophet, preliminary, 1QS IX):

$[R]$ egulations for the Instructor by which he shall walk with every living being in compliance with the circumstances of every period and in compliance with the worth of every man. (col. 12)

It is not clear whether the current flexible approach to the 'counsel of the law' of the Instructor will also apply to the coming prophet. There are also indications of an expectation of the Deuteronomic prophet among the Samaritans (Memar Merqah 4:12; see Barrett 1994:208; Marshall 2007:548).

This development may be due to the notion of the cessation of prophecy, so that the (further) fulfilment of the Mosaic prediction was eagerly expected for the future. However, this explanation has been challenged. While there is evidence in some sources for the absence of the prophetic voice which had accompanied Israel throughout its history (see e.g. 1 Macc 4:46; 9:27; 14:41; 2 Bar 85:1-3, see Aune 2010:1101; Hawthorne 1992:637), other evidence suggests that - at least for some Jews - prophets and prophecy was a present experience (for a survey of the evidence, see Gray 1993:7-111; see e.g. Jn 11:49-52). When asked by the crowds whether he is the Messiah, Elijah redivivus or the prophet, John the Baptist denied being this figure (Jn 1:21,25; see Hawthorne 1992:639).

Some people claimed to be prophets were hailed as messianic prophetic figures and on several occasions drew large crowds of people after them. Josephus Flavius mentions a number of such figures and their fate. Often they and their followers were routed and killed by the Roman overlords who were quick to intervene (see Aune 2010:1099; Gray 1993:112-144). It is difficult to determine whether and to what extent these figures were identified in particular with the prophetic figure of Deuteronomy 18 (see Aune 2010:1099). Against this backdrop it is hardly surprising that some contemporaries of Jesus wondered whether he could be this prophet.

\section{Jesus as the prophet of Deuteronomy 18 in the gospels ${ }^{14}$}

The many and striking parallels between his ministry and that of the Old Testament prophets (for a survey, see Hawthorne 1992:640) led some Jews to interpret Jesus' appearance and ministry as that of a prophet (see Poirier

13.Barrett (1994:208) rightly notes that the passage "seems to treat the prophet like Moses as a messianic figure, though not as the Messiah'. Perhaps in view of historical experiences, Philo 'goes even less far (De Spec. Leg. I.65). Mose recognised men's longing to know the future, and in forbidding them to use haruspicy and other forms of divination promised the coming of a prophet'. Clem. haruspicy and other forms of divis Recog. 1.43 assumes that interpretation. However, Barrett (1994:208) concludes: 'This is justified only in respect of the Qumran passages quoted above, and then only in the broadest
terms'.

14.For surveys, see Poirier (2008) and Rowland (2013:707-708); for the wider reception of Moses in the New Testament, see Hay (1990). 
2008:466-467). Jesus was identified with the ancient prophets in general, risen from the dead (as one of them, Mt 16:14; Mk 6:15, 8:25; Lk 9:8, 19; see also Mk 14:65) or Elijah redivivus or Jeremiah in particular (Mt 16:14; see Poirier 2008:467). Clearly Jesus had a prophetic self-consciousness (Lk 4:24, 13:33; for a survey, see Hawthorne 1992:640-641; Rowland 2013:706).

Our interest is the instances when Jesus is identified as the (Deuteronomic) prophet. ${ }^{15}$ After the feeding of the 5000 (with all the reminiscences of Moses feeding Israel during its desert wanderings), the people are said to be impressed with this sign and to conclude: 'This is indeed the prophet who is to come into the world' (Jn 6:14; see also 1:21). ${ }^{16}$ In response to the claims of Jesus to be the eschatological dispenser of living water, some in the crowd gathered: 'This is really the prophet' (Jn 7:40). Others inferred that Jesus is the Messiah (Jn 7:41). The opponents of Jesus challenged this identification with reference to the Galilean origin of Jesus. Therefore, he cannot be the prophet (Jn 7:52): 'Search and you will see that no prophet is to arise from Galilee'.

Possibly there are two other occurrences of the prophet like Moses. The healed blind man reckons that Jesus is a prophet (Jn 9:17). In Luke 7:16 the people judged: 'A great prophet has risen among us'. In both cases it is not clear whether the reference is to the Deuteronomic prophet.

Although his ministry has striking parallels to that of Moses (in some regard, Jesus is presented as the 'new Moses'; for a detailed discussion of Mosaic Christology, see Hatina 2008; Lierman 2004), according to the Gospels, Jesus never directly identified himself with the Deuteronomic prophet or addressed the identification of himself with this figure (as he did with reference to Elijah; see Litwak 2013). There is one reference by Jesus to the testimony of Moses, which beyond a general claim (such as in Lk 24:27, 44: 'And beginning with Moses and all the Prophets, he interpreted to them in all the Scriptures the things concerning himself'), may be an indirect self-identification of Jesus with the prophet announced by Moses. In John 5:46, Jesus claims: 'For if you believed Moses, you would believe me; for he wrote of $\mathrm{me}^{\prime} .{ }^{17}$

According to the Gospels, the term is never used by others in addressing Jesus (see e.g. the use of 'Son of David' in Lk 18:28-29). For his followers, Jesus came to be more than a prophet: he was the Messiah (Mk 8:29). The appearance of Moses (as a separate figure) at the transfiguration might have removed any doubt.

While there are many similarities between the ministry of Jesus and that of the prophets of the Old Testament and of

15.Possibly some contemporaries referred with the designation 'the prophet' not to the Deuteronomic prophet like Moses but to the prediction of the return of Elijah redivivus in Malachi 3 (see Poirier 2008:467). However, it seems that the Gospel writers distinguish between the different identifications.

16.For a detailed discussion of the Johannine passages, see Keener (2003) and Labahn (2007).

17.Thyen (2005:329-339) argues that for John the relationship between Moses and Jesus is far more profound than individual predictions such as Deuteronomy 18:18-19. early Judaism, there were also significant differences between him and prophetic figures. Despite these differences some of Jesus' contemporaries apparently came to see him as the Deuteronomic prophet. This Deuteronomic figure provided them with a biblical and benevolent category for explaining the miracles of Jesus and his teaching ministry and claims regarding his identity and significance. Jesus' opponents provided a contrasting explanation (Mk 3:22). It is not clear how the people would have related this identification of Jesus to other figures and to the Mosaic Law. In view of this interpretation by some people, it is interesting to see whether and how this figure featured in early Christian proclamation.

\section{Jesus as the prophet of Deuteronomy 18 in Acts 3 and $7^{18}$}

The clearest and most extensive reception of the Deuteronomic prophet in the New Testament occurs in Acts 3. In his second missionary speech in Jerusalem (Ac 3:12-26), Peter identifies Jesus as the prophet like Moses by quoting Deuteronomy 3 :

Moses said: 'The Lord your God will raise up for you from your own people a prophet like me. You must listen to whatever he tells you. And it will be that everyone who does not listen to that prophet will be utterly rooted out of the people'. (vv. 22-23)

At the same time, Jesus surpasses the prophet like Moses. ${ }^{19}$ Regarding the function of this reference, Pervo (2009) observes:

This portion of the speech supports the claim that all has happened in accordance with God's plan by appeal to prophetic tradition, not, however, by citing an apocalyptic text, but through asserting that Jesus is the 'prophet like Moses' predicted in Deuteronomy 18:15. ... Although a good deal of material from disparate sources suggests the development of a prophet with messianic features, Luke's 'prophetic Christology' follows a different path. For Luke, (the earthly) Jesus is more a prophet like Moses (and Elijah, etc.) than a messiah endowed with prophetic qualities..$^{20}$ (p. 108)

The identification of Jesus as the prophet like Moses adds a new aspect to the portrayal of Jesus in Peter's speeches in Acts 2-3 (for a full survey of the Christology of these speeches, see Schnabel 2012; Stenschke 2014). While there was no prophet like Moses in the history of Israel - so the conclusion in Deuteronomy 34:10-12 - Jesus now is a worthy successor of him and more than Moses.

18.For a detailed treatment, see Marshall (2007) and Rusam (2003). For the other use of Deuteronomy in Luke-Acts, see Rusam (2007).

19.Chianeque and Ngewa (2006:235) rightly emphasise that in Acts Jesus is at the same time more than this prophet: He is 'a prophet far greater than any of those who had preceded him. He is "the Holy and Righteous One" (Acts 3:14; 7:52), "the author of life" (Acts 3:15) and "the Christ" (Acts 3:18) whom the other prophets foretold. Yet he is more like Moses than any prophet of the OT in that just as Moses was central to the giving of the old covenant (the commandments) on Mount Sinai, so Jesus is central to the new covenant'.

20.Pervo (2009:108-109) notes that 'Deut 18:15-20 was a key text in early Christianity (Mark 9:7 parr.; John 1:21; 5:46; Luke 7:39; 24:25; as well as Acts 7:37'. At the end of a brief comparison of the references to the Deuteronomic prophet in John, of a brief comparison of the references to the Deuteronomic prophet in John, text which he claims has been fulfilled in Jesus'. The reference in Acts is a 'primitive testimonium, probably the origin of Jn 6:14)' (p. 207): 'Probably Luke is simply testimonium, probably the origin of Jn 6:14)' (p. 207): 'Probably Luke is simply
following here what had in his time become an accepted Christian testimonium. Jesus fulfilled all the messianic promises' (p. 208). 
The quotation from Deuteronomy occurs in a context abounding with prophecy: through the course of the events in Jerusalem, God fulfilled what he had foretold through all of the prophets, that his Messiah would suffer (Ac 3:18). God announced the time of universal restoration long ago through his holy prophets (Ac 3:21). 'All the prophets' have predicted these days of fulfilment and restoration (Ac 3:24). The audience is designated as descendants of the prophets and of the covenant (Ac 3:25), that is, they inherit the promises made by the prophets. Like the prophets of old were called to do, Jesus is called to 'bless you by turning each of you from your wicked ways' (Ac 3:26). Steyn (1995:150) concludes: 'The quoted phrases from Deut 18 are now presented as an example of such a promise of the times of restoration, as implied in the previous verses'. These references follow the coming of the Spirit at Pentecost in Acts 2. Rowland (2013) notes that Acts 2:

$[E]$ ncapsulates as well as any the view that prophecy is in some sense not just 'fulfilled' but actually renewed and, indeed, restarted. ... The introduction 'in the last days' sets the tone for the significance of what is happening and marks the moment as eschatological. (p. 706)

The risen Jesus pours out the eschatological Spirit. As the Deuteronomic prophet, he restarts and renews prophecy. He is the eschatological figure who fits this eschatological moment.

Marshall (2007:547) notes that Peter develops the application of the Deuteronomic prophet to Jesus in terms 'of the typology between the people of Israel and their prophets and the Jews and Jesus' (on typology, see Treier 2005). As Israel did and should have listened to the prophets rather than rejecting them, so the Jews of Jerusalem listened and should have listened to Jesus and not reject him. Just as God will raise (anastēsei) up the prophet like Moses from among the Israelites (Ac 3:22), ${ }^{21}$ so God raised up Jesus from the dead (see the occurrences of this word in Ac 2:24, 32; 3:26; 7:37). Says Steyn (1995):

The fact that the lame man could have been raised by Peter and John, proved that Christ was raised. Thus the prophecy has come true, and is confirmed as being the words of God himself. (p. 152)

In addition to forceful accreditation through the signs and miracles of Jesus (emphasised in Ac 2:22; some of which recall the ministry of Moses; see Dt 34:11-12), God has given his full approval and attestation to this prophet by raising him from the dead. While God buried Moses (Dt 34:1-8), he raised this prophet like Moses, the eschatological figure, as a turning point in the history of Israel.

How could the Messiah, the 'anointed one', be identified with a prophet? According to Schnabel (2012:217), an early Jewish text helps in making this identification understandable. The Moses Apocryphon (4Q377 frag 2, II, 3-5) describes Moses as God's Anointed (for a detailed examination, see Zimmermann 1998:332-342):

21.The combination of 'raising up' with reference to people recalls the divine provision of prophets and other figures such as judges elsewhere in the Old Testament.
In the text Moses appears not only as God's counterpart (as the people), but as God's agent and plenipotentiary, as mediator between God and the people. If Moses can be called 'The Anointed', the same must apply to the 'prophet like Moses'. (Schnabel 2012:217)

The comparison with the text of Deuteronomy 18 indicates that the author of Acts cites the prophecy rather 'selectively and loosely' (Marshall2007:547): 'Although this phraseological quoted text from Deuteronomy 18 is not quoted verbatim in its entirety, it is clearly apparent that it is based on the LXX' (Steyn 1995:149).22 After explanations, Marshall (2007) translates the LXX as follows:

$[W]$ ith differences in its citation in Acts (variation: italicized text in braces; addition: plus sign [+] followed by italicized text in braces; omission: minus sign [-] followed by plain text in parentheses).

15 The Lord your \{your [pl.]\} God will raise for you \{you [pl.]\} a prophet like me from among your brothers; you shall listen to him, 16 according to everything that $\{+$ he says to you [pl.]\} ... \{+ But every soul [Lev. 23:29]\} who does not listen to (- all that) that prophet (- says in my name, $\{+$ will be cut off from the people [Lev. 23:29]\} ( - I will call him to account). ${ }^{23}$ (p. 547)

The deviations from the Greek text (abbreviation by the omission of Dt 18:16b,17,18,19a, alternation of the wording accordingly, conflation with Lv 23:29 in v. 23) are probably due to the author of Acts. Others have suggested that these phrases in Acts 3:22-23 were already combined in early Christianity before the author's time (see Marshall 2007:547). However, this assumption 'remains problematic, questionable and unprovable' (Steyn 1995:142). It is therefore safer to assume that the text as it stands in Acts 3 presents Luke's editorial work.

While the rendering in Acts 3 mainly consists of abbreviations and minor changes due to the new context in Acts which do not change the meaning significantly (for a survey, see Steyn 1995:149), two differences are striking. As 'there is no support from any LXX witnesses in favour of these changes' (Steyn 1995:148), they should probably be ascribed to Luke. By conflating Deuteronomy 18 with Leviticus 23:29 at the beginning of Acts 3:23, Luke changes 'the man (who does not listen)' to the more comprehensive expression 'but every soul' (pasa psyche).

The end of Acts 3:23 explicates the prospect of 'being held accountable' by God (so the Hebrew text) or the 'rather bare' (Marshall 2007:548) declaration 'I will punish' (enteilomai: so the LXX text of Dt 18:19) by drawing on

22. Marshall offers an instructive chart of both texts. For a detailed treatment, see Steyn (1995:140-153). Steyn (1995:140-141) speaks of 'explicit references, created by the author by his skilful combination of several different passages, and explicitly and consciously linked with those reading(s) of the OT texts themselves'. Therefore, 'Acts 3:22-23 could be treated as a paraphrase of Deut 18:15-20,21 which was summarised by the author by way of a complex combination of phrases (from the rummarised by the author by way of a complex combination of phrases (from the referred passage) in an order that suited his purpose within the context of his time' (Steyn 1995:141). Steyn offers a detailed discussion of the textual differences between Acts $3: 22$ and Deuteronomy 18:15-16,19 (LXX). See Lim
(2007:18-20) for an analysis of the LXX version of Deuteronomy.

23.On the omission, Steyn (1995:147) notes: 'The Deut content of this omitted section does not fit the new context of this speech in Acts at all, and its exclusion thus makes sense here'. 
Leviticus 23:29 as follows: 'who does not listen to that prophet will be utterly rooted out of the people' (exolethreuthesetai ek tou laou; see also Lv 7:29-21). ${ }^{24}$ The Israelites who do not listen to Moses and disobey God's command by not fasting on the entire day of atonement 'shall be cut off from the people' (exolethreuthèsetai ek tou laou autēs; for the meaning, see Wenham 1979:241-242; see also Lv 23:30: 'I will destroy from the midst of the people'). ${ }^{25}$ On Luke's procedure, Steyn (1995) surmises:

Luke himself may have compiled the curse here, within the framework of the nature of this law-material, which seems always to be combined with the curse. He would have done this with the help of this knowledge of the well-known terminology used in the Torah, as well as with the help of the rest of the context of Deut 18(:19). (pp. 148-149)

Through this change the consequences of rejecting Jesus are intensified. One Old Testament announcement of divine judgement is replaced by another, more explicit and serious one. Expressed also in Old Testament language, the text presents a severe warning: God himself will punish those who refuse to listen to Jesus. It is not a punishment for humans to execute. In both passages, Moses is speaking (see the introductory formula to this paraphrase, 'Moses said'); both passages address the serious consequences of disobeying divine command.

What is the significance and function of applying this quotation from Deuteronomy to Jesus? With the identification of Jesus as the Deuteronomic prophet like Moses, Jesus receives the testimony of Moses, perhaps the most significant figure in early Judaism (see Falk 2010). Jesus is not only the promised descendant of David and attested to by David's prophecy as emphasised in Acts 2 (through the references to the prediction of (a) prophet(s) like Moses, Acts 2 identifies David in retrospect as a prophet), but also the prophet announced by Moses. To remove any doubt, Peter mentions Moses by name: no less a figure than Moses predicts the coming of Jesus and commands the people to heed to him. Thus, all who want to and claim to listen to Moses and obey him (which should be the desire of the Jewish audience in Jerusalem!), had better listen to this prophet Jesus. Schnabel (2012) aptly comments:

The future tense translated as 'you must listen to him' ... expresses a strict commandment and the meaning is an equivalent to 'obey'. The people of Israel are obliged to listen to this future prophet 'in everything that he tells you', i.e. in all matters that he communicates from God, without exception. (p. 218)

24.The change in the text of Acts may have been influenced by the immediate context of Deuteronomy 18. The fate of prophets who speak in the name of other gods or speak God's word without having been commissioned by him (Dt 18:20) - namely 'that prophet shall die' - may be applied to those who refuse to listen to the prophet like Moses.

25.According to Hartley (1992:388), the 'cut-off' penalty means that God himself is the one who takes responsibility for punishing any who violate these laws. Steyn (1995:148) observes that 'the formula itself seems to be typical of the literature which deals with the obedience to God's law, and the disobedience to the law which deals with the obedience to God's law, and the disobedience to the law
seems to be closely linked with this curse - which is found extensively in the OT'.
Moses not only charges to listen, but also gives stern warnings to those who refuse to listen. Schnabel (2012) notes that:

$[O]$ bedience to the coming messianic prophet is the criterion by which God decides whether people remain in Israel or are removed from his people. Continued membership in the people of God is dependent on a positive response to the Messiah. (p. 218)

Rejecting Jesus and the proclamation of Jesus as Messiah, Lord and eschatological prophet like Moses means judgement. The division among the people of God (emphasised by Jervell 1996) - to which the proclamation of the Gospel leads - is thus by no means harmless.

The very belonging to the people of God is at stake. 'The shift from the wording of Deuteronomy indicates as clearly as possible that continued membership in the people of God is dependent on a positive response to the Messiah' (Marshall 2007:548). The application of these predictions to Jesus implies a new definition of the people of God: membership is no longer determined by birth or the knowledge and practice of the Law of Moses but by obedience to the prophet like Moses, that is Jesus. In an indirect way, this position of Jesus opens the way of including Gentiles into the people of God.

At first sight, the judgement of 'being rooted out of the people' (Ac 3:23) does not leave much hope for people who refuse to obey. Through their refusal of acknowledging Jesus, some Jews forgo their privileged position of belonging to the people of God. This statement regarding the re-definition of the nature and boundary of the people of God must be seen in the wider context of other statements regarding Israel in Luke-Acts (for a survey, see Jervell 1996; Schaefer 2012).

Therefore, not only Peter with his disputed apostolic authority (see the conflicts of Ac 4-5) claims a special status and role for Jesus, but also Moses as the undisputed authority in early Judaism: Moses, not the apostles, warns against rejecting Jesus. The identification of Jesus with the prophet like Moses prepares for the conflict of the apostles with the religious leaders in Acts $4-5$. The apostles claim the heritage of Moses for Jesus and the Gospel. When the religious leaders reject Jesus, they discredit themselves. They not only forfeit their leadership role, but also their very belonging to the people of God. By definition, the prophet and his followers surpass the religious establishment (Rowland 2013):

The sense of the present communion with the divine, in which tradition and accepted channels of authority are relativized by the prophet's conviction that his vision or word has an authority, which is at least as great as that of the authoritative texts from the past [one may add the authoritative institutions], typifies much of what is central to the New Testament. (p. 709)

Marshall (2007:548) notes that the reference to the prophet being raised up 'from among your own people' emphasises Jesus' Jewish identity, which corresponds with the emphasis on Jesus as a descendant of David. As a Jew he fulfils the 
promises and was sent to the Jewish people first (Ac 3:26; see Stenschke 2018).

This identification of Jesus is also noteworthy against the backdrop of the accounts of some prophets in contemporary Judaism and the dire consequences which their appearance and claims had for them and their followers (see above). In this light, Jesus is cast as the true successor-prophet of Moses and confessed to be this figure, not the messianic claimants of his day and age. Luke's Gospel underscores that Jesus was different from them: he was not an instigator but was rejected by his own people. He died according to the will of God. When he died, none of his followers or from among the crowds suffered harm. He did not use or threaten to use the supernatural powers truly available to him against his enemies. This consideration contributes to one of the several apologetic aims of Luke-Acts. Jesus and his followers are not a threat to their Roman overlords and should be tolerated. The one whom Christians claim to be the Messiah and true prophet like Moses did not use violence; he allowed himself to be arrested, did not offer resistance, died and when dying asked for forgiveness for those who crucified him. The apologetic approach of Luke-Acts to prophets differs from Josephus' scathing and polemic characterisation of such prophets and prophetic movements in Jewish War 2.259 (see also Ant 20.167-171):

Deceivers and imposters, under the pretence of divine inspiration fostering revolutionary changes, they persuaded the multitude to act like madmen, and led them out into the desert under the belief that God would there give them tokens of deliverance.

In this way, Luke also provides a defence not only of the followers of Jesus but also of Judaism: not the people like those maligned by Josephus (and killed by the Romans!) are the true fulfilment of the prediction of Deuteronomy and legitimate heirs of the Jewish tradition, but Jesus and his followers. They do not represent Judaism, but he. At the same time, Peter's identification is also critical of Roman claims. The counter-imperial message beneath the surface of the text is that Jesus and no one else - be they Jewish or Gentile - is truly God's agent. Jesus is the one Son of God, not the emperor in Rome (for methodological issues, see Heilig 2015).

It is noteworthy that Peter does not go on quoting Deuteronomy with its instructions on distinguishing true from false prophets. Such instructions are not necessary in the case of Jesus, as God had so generously attested Jesus: 'Jesus of Nazareth, a man attested to you by God with deeds of power, wonders, and signs that God did through him, as you yourselves know' (Ac 2:22; note the echoes of Dt 34:1112; see the many accounts of the miracles of Jesus in Luke's Gospel and other references to them in the missionary speeches of Acts). In addition, Jesus himself has proved to be a true prophet: the predictions concerning his passion, death and resurrection had come true (Lk 9:22, 44; 18:31-34). Neither does Peter give the kind of instructions on testing the validity of Christian prophecy which appear elsewhere in the New Testament.
The identification of Jesus with the Deuteronomic prophet like Moses makes an important contribution to the presentation of Jesus in the missionary speeches of Acts. It highlights the significance of Jesus and emphasises what is at stake in refusing to respond to him. In addition, it is the very Moses who re-defines the people of God as those who listen to Jesus and follow him.

In Acts 7:37, the only other reference to Deuteronomy 18 in Acts, Moses is explicitly identified as the one who announced the coming of a future prophet: 'This is the Moses who said to the Israelites: "God will raise up for you a prophet like me from your brothers"' (detailed treatment in Rusam 2007:8081). ${ }^{26}$ In the context, Stephen highlights three key elements of Moses' career (Pervo 2009):

[O]ver forty years (cf. vv. 23, 30; 13:21) he exercised his leadership through working miracles, foretold the coming of a prophet like himself, and received the revelation at Sinai. The first two establish him as a prototype of Jesus, while the third disposes of the charge that Stephen reviled Moses and the Torah $(6: 11,13)$. (p. 188)

\section{Summary and implications}

In the course of the reception history, Moses' prediction of another prophet or other prophets through whom God would communicate with his people as he had done through Moses took several interesting turns. What was originally intended as an assurance that God would continue to speak to his people through special agents from among the people (in contrast to the practices of the nations of Canaan) became in early Judaism a prediction of a particular eschatological prophetic figure. In view of the situation of Israel at the time this eschatological interpretation is understandable. This demanding situation forms the backdrop to the instances in early Jewish history when individual figures were identified as prophets and gained followers. While some of his Jewish contemporaries merely wondered whether Jesus of Nazareth could be this eschatological prophet like Moses, or were even convinced of this identification, the early Christian proclamation - according to Acts - left no doubt that Jesus is precisely this figure. It could apply the designation 'prophet like Moses' to Jesus because at this time the Deuteronomic prediction of a prophet like Moses was understood as referring to a unique, eschatological figure. This identification meant that the full authority of Moses is now behind Jesus. Bridging the centuries since his days, Moses now directly commends Jesus and commands the people to listen to him. Without this development of a particular eschatological understanding, the designation of Jesus as prophet like Moses would not have meant more than what some people thought of Jesus before Easter anyway. By conflating the quotation from Deuteronomy with Leviticus - thus intensifying it - Acts makes Moses express the stern warning that with the response to Jesus the very belonging to the people of God is at stake.

26.The expression 'this Moses' occurs several times in this summary of the career of Moses. Zehnle (1971:75-89) traces the various aspects of the Moses typology and their relevance for Acts. 
In the course of its reception up to the New Testament, an assuring word and implicit warning against the mantic practices of neighbouring nations became in its New Testament reception a claim that God is behind this Jesus who was rejected by the people but raised by God and a stern warning against refusing to listen to Jesus. In this process, there is an element of continuity: forsaking God's word as mediated through the Law, Moses and later prophets, endanger the identity of the people of God and lead to loss of membership in the people of God. The same danger is impending where Jesus is not heeded and accepted.

This identification sheds light on the creative use of Scripture in early Judaism (and with it, early Christianity). The Old Testament is understood as shedding light on current events, its predictions are being fulfilled in the present and further fulfilment is to be expected. Luke's use of Deuteronomy 18 shows how and to what extent early Christian Christology/ theology was based on concepts from the Scriptures (see Steyn 1995:152-153). Luke's conflation of two passages needs to be understood in the wider context of his use of the Old Testament elsewhere (see Marshall 2007; Rusam 2003) and of the exegetical/hermeneutical practices of his own day.

Before we address some present-day implications of this portrayal of Jesus, it is worthwhile to ask why the identification of Jesus as the prophet like Moses does not appear elsewhere in the New Testament. It might not have been used more often as the designation and concept of prophet(s) would not have been fully comprehensible in nonJewish contexts. In addition, while Jesus was the unique prophet like Moses, the early Christians would have agreed that Jesus was far more than this prophet. This designation was not sufficient to express the high Christology which they held. In the words of Hawthorne (1992):

$[T]$ hough Jesus did understand himself as a prophet - a Spiritinspired and Spirit-empowered person - and his ministry as a prophetic ministry, yet neither Jesus nor the Evangelists would have stopped there. For both Jesus himself and the Evangelists, he was 'a prophet, yes, but more than a prophet' ...; he was the unique Son of the Father ... the Son of God. (p. 641)

Several aspects of this identification are of abiding significance:

As Jesus is confessed to be the true prophet like Moses, listening to his words and obedience to them are characteristics and requirements of true discipleship. The willingness to listen to him and ensuing obedience to his words determines membership in the people of God, which is closely linked to salvation. This resembles other absolute statements in the New Testament, such as John 14:6 and Acts 4:12, regarding the significance of Jesus. Acts emphasises that the stance which people take towards Jesus not only determines their individual salvation but also their membership in God's people. This collective aspect of salvation should not be neglected in evangelism, confession of faith, the baptism of believers and discussions of discipleship/ethics. Christians are first and foremost people who obey Christ.
In contexts where prophets and prophecy are popular, one should be careful to distinguish between the unique position of Jesus as the eschatological prophet like Moses and other prophets as they appear not only in early Judaism but also in the Christian communities of the New Testament. Although their ministry is portrayed positively throughout (when true and distinguished from false prophets), they are never at 'eye-level' with Jesus as the decisive prophetic agent of God. The particular significance of Jesus as the prophet like Moses relativizes all Christian prophetic claims and practice. Chianeque and Ngewa (2006:235) observe that ' $[t]$ oday in Africa there are dozens of new denominations founded on the basis that a leader heard the voice of God or had a revelation'. ${ }^{27}$ Few of the people who appear with prophetic self-confidence claim to be the prophet like Moses. Divine attestation and fulfilment of his prophecies indicated Jesus' divine calling as this prophet (including suffering and death!). Those who make prophetic claims for themselves today should be prepared to provide some evidence.

What Moses and prophets like him revealed in the name of the LORD was sufficient for Israel. The Israelites had no need to look elsewhere (Dt 18:9-14) and were forbidden to do so. What God revealed in Jesus, the prophet like Moses (and legitimate Christian prophets), is likewise sufficient for the church and the world. They have no need to look elsewhere for divine revelation.

Martin Luther King spoke in Memphis, Tennessee, on the evening before he was assassinated on 04 April 1968, 52 years ago. In this speech, which came to be called 'I have been to the mountaintop', the Baptist pastor and human rights activist referred to Deuteronomy 34:

Then Moses climbed Mount Nebo ... There the Lord showed him the whole land ... Then the Lord said to him, 'This is the land I promised on oath to Abraham, Isaac and Jacob ... I will let you see it with your eyes, but you will not cross over into it'. (vv. 1-4)

King did not claim to be the prophet like Moses, but likened himself in this prophetic analogy to the situation of Moses on the verge of his death. God allowed Moses to see the Promised Land, but he could not enter it. King (1968) said:

Like anybody, I would like to live a long life. Longevity has its place. But I'm not concerned about that now. I just want to do God's will. And He's allowed me to go up to the mountain. And I've looked over. And I've seen the Promised Land. I may not get there with you. But I want you to know tonight, that we, as a people, will get to the Promised Land! And so I'm happy, tonight. I'm not worried about anything. I'm not fearing any man! Mine eyes have seen the glory of the coming of the Lord! (n.p.)

In this essay we have touched on some of the trajectories of the reception history of the Deuteronomic prophet like Moses. We have not looked at the full reception of Deuteronomy 18 in the Old Testament, elsewhere in Second Temple and Hellenistic Judaism (see Lim 2007) and in Rabbinic, medieval and modern Judaism, in later Christianity, in Islam, possibly in other religions, in literature, visual arts,

27.For a nuanced assessment, including the 19th-century Xhosa prophets Ntsikana and Molageni, see Ouedraogo (2006); see also Sundkler and Steed (2000). For a discussion of less contentious models of African Christian leadership, see Priest and Barine (2017). 
music and films. ${ }^{28}$ It would be instructive to place the trajectories of the reception in the New Testament which we examined here into this wider picture.

\section{Acknowledgements}

\section{Competing interests}

The author has declared that no competing interests exist.

\section{Author's contributions}

I am the sole author of this article.

\section{Ethical consideration}

This article followed all ethical standards for research without direct contact with human or animal subjects.

\section{Funding information}

This research received no specific grant from any funding agency in the public, commercial or not-for-profit sectors.

\section{Data availability statement}

Data sharing is not applicable to this article as no new data were created or analysed in this study.

\section{Disclaimer}

The views and opinions expressed in this article are those of the author and do not necessarily reflect the official policy or position of any affiliated agency of the author.

\section{References}

Aune, D.E., 1983, Prophecy in early Christianity and the ancient Mediterranean world, Eerdmans, Grand Rapids, MI.

Aune, D.E., 2010, 'Prophecy', in J.J. Collins \& D.C. Harlow (eds.), The Eerdman dictionary of early Judaism, pp. 1099-1101, Eerdmans, Grand Rapids, MI.

Barrett, C.K., 1994, A critical and exegetical commentary on the Acts of the Apostles I: Preliminary introduction and commentary on Acts I-XIV, ICC, T \& T Clark, Edinburgh.

Barton, J., 1992, 'Prophecy (postexilic Hebrew)', in D.N. Freedman (ed.), Anchor Bible dictionary, vol. 5, pp. 489-495, Doubleday, New York, NY.

Beale, G.K. \& Carson, D.A. (eds.), 2007, Commentary on the New Testament use of the Old Testament, IVP, Nottingham.

Chianeque, L.C. \& Ngewa S., 2006, 'Deuteronomy', in T. Adeyemo (ed.), Africa Bible commentary, pp. 209-254, WordAlive, Nairobi.

Christensen, D.L., 2001, Deuteronomy 1:1-21:9, 2nd edn., WBC 6a, Nelson, Nashville, TN. Cook, S., 2004, The social roots of Biblical Yahwism, SBL, Atlanta, GA.

Crawford, S.W., 2013, 'Deuteronomy, Book of III. Judaism A. Second Temple and Hellenistic Judaism', in D.C. Allison, H.-J. Klauck, V. Leppin et al., Encyclopedia of the Bible and its Reception, vol. 6, pp. 665-667, De Gruyter, Berlin.

Falk, D.K., 2010, 'Moses', J.J. Collins \& D.C. Harlow (eds.), The Eerdmans dictionary of early Judaism, pp. 967-970, Eerdmans, Grand Rapids, MI.

Fuhrmann, S., 2013, 'Deuteronomy, Book of II. New Testament', in D.C. Allison, H.-J. Klauck, V. Leppin et al., Encyclopedia of the Bible and its Reception, vol. 6, pp. 658-665, De Gruyter, Berlin.

Gray, R., 1993, Prophetic figures in late Second Temple Jewish Palestine: The evidence from Josephus, Oxford University Press, Oxford.

Hartley, J.E., 1992, Leviticus, WBC 4, Word, Dallas, TX.

Hatina, T.R., 2008, 'Moses', in C.A. Evans (ed.), Encyclopedia of the historical Jesus, pp. 420-422, Routledge, New York, NY.

Hay, D.M., 1990, 'Moses through New Testament spectacles', Interpretation, 64, 240-252.

28.Following the structure of the entries in the Encyclopedia of the Bible and its Reception (EBR), for example 'Abraham' in EBR I (2009):149-204.
Hays, R., 1989, Echoes of scripture in the letters of Paul, Yale University Press, New Haven, CT.

Hawthorne, G.F., 1992, 'Prophets, prophecy', in J.B. Green, S. McKnight, I.H. Marshall (eds.), Dictionary of Jesus and the gospels, pp. 636-643, Intervarsity Press, Downers Grove, IL.

Heilig, C., 2015, Hidden criticism? The methodology and plausibility of the search for a counter-imperial subtext in Paul, WUNT II.392, Mohr Siebeck, Tübingen.

Jervell, J., 1996, The theology of the Acts of the Apostles, New Testament Theology, Cambridge University Press, Cambridge.

Keener, C., 2003, The gospel of John: A commentary, Hendrickson, Peabody, MA.

King, M.L., 1968, 'I have been to the mountain top', viewed 20 December 2018, from https://www.americanrhetoric.com/speeches/mlkivebeentothemountaintop. htm.

Koch, D., 1986, Die Schrift als Zeuge des Evangeliums: Untersuchungen zur Verwendung und zum Verständnis der Schrift bei Paulus, BHTh 69, Mohr, Tübingen.

Labahn, M., 2007, 'Deuteronomy in John's gospel', in S. Moyise \& M.J.J. Menken (eds.), Deuteronomy in the New Testament: The New Testament and the scriptures of Israel, pp. 82-98, LiNTS 358, T. \& T. Clark, London.

Lierman, S., 2004, The New Testament Moses: Christian perceptions of Moses and Israel in the setting of Jewish religion, WUNT II.173, Mohr Siebeck, Tübingen.

Lim, T.H., 2007, 'Deuteronomy in the Judaism of the Second Temple period', in S. Moyise \& M.J.J. Menken (eds.), Deuteronomy in the New Testament: The New Testament and the scriptures of Israel, pp. 6-26, LiNTS 358, T. \& T. Clark, London.

Litwak, K., 2013, 'Elijah and Elisha', in J.B. Green, S. McKnight \& I.H. Marshall (eds.), Dictionary of Jesus and the gospels, 2nd edn., pp. 229-232, Intervarsity Press, Downers Grove, IL.

Marshall, I.H., 2007, 'Acts', in G.K. Beale, \& D.A. Carson (eds.), Commentary on the New Testament use of the Old Testament, pp. 513-606, IVP, Nottingham.

Moyise, S. \& Menken, M.J.J. (eds.), 2007, Deuteronomy in the New Testament. The New Testament and the scriptures of Israel, LiNTS 358, T. \& T. Clark, London.

Olson, D.T.S., 2013, 'Deuteronomy, book of I. Hebrew Bible/Old Testament', in D.C. Allison, H.-J. Klauck, V. Leppin et al., Encyclopedia of the Bible and its Reception, vol 6, pp. 653-658, De Gruyter, Berlin.

Otto, E., 2012, Deuteronomium 1,1-4,43, HThKAT, Herder, Freiburg.

Otto, E., 2016, Deuteronomium 12,1-23,15, HThKAT, Herder, Freiburg.

Otto, E., 2017, Deuteronomium 23,16-34,12, HThKAT, Herder, Freiburg.

Ouedraogo, A., 2006, 'Prophets and Apostles', in T. Adeyemo (ed.), Africa Bible commentary, p. 1434, Word Alive Publishers, Nairobi.

Pervo, R.I., 2009, Acts: A commentary, Hermeneia, Fortress, Minneapolis, MN.

Poirier, J.C., 2008, 'Prophecy', in C.A. Evans (ed.), Encyclopedia of the historical Jesus, pp. 465-468, Routledge, London.

Priest, R. \& Barine, J.K. (eds.), 2017, African Christian leadership: Realities, opportunities and impact, American Society of Missiology Series 54, Orbis, Maryknoll, NY.

Römer, T.C., 2009, 'Das Verbot magischer und mantischer Praktiken im Buch Deuteronomium (Dtn 18,9-13)', in T. Naumann \& R. Hunziker-Rodewald (eds.), Diasynchron: Beiträge zur Exegese, Theologie und Rezeption der Hebräischen Bibel, pp. 311-327, Kohlhammer, Stuttgart.

Rowland, C., 2013, 'Prophets, prophecy', in J.B. Green, S. McKnight \& I.H. Marshall (eds.), Dictionary of Jesus and the gospels, 2nd edn., pp. 705-710, Intervarsity Press, Downers Grove, IL.

Rusam, D., 2003, Das Alte Testament bei Lukas, BZNW 122, De Gruyter, Berlin.

Rusam, D., 2007, 'Deuteronomy in Luke-Acts', in S. Moyise \& M.J.J. Menken (eds.), Deuteronomy in the New Testament: The New Testament and the scriptures of Israel, pp. 64-81, LiNTS 358, T. \& T. Clark, London.

Schaefer, C., 2012, Die Zukunft Israels bei Lukas: Biblisch-frühjüdischeZukunftsvorstellungen im lukanischen Doppelwerk im Vergleich mit Römer 9-11, BZNW 190, De Gruyter, Berlin.

Schmitt, J.J., 1992, 'Prophecy (preexilic Hebrew)', in D.N. Freedman (ed.), Anchor Bible dictionary, vol. 5, pp. 482-488, Doubleday, New York, NY.

Schnabel, E.J., 2012, Acts, Exegetical Commentary on the New Testament, Zondervan, Grand Rapids, MI.

Seeman, C. \& A.K. Marshak, 'Jewish history from Alexander to Hadrian', in J.J. Collins \& D.C. Harlow (eds.), The Eerdmans dictionary of early Judaism, pp. 25-55, Eerdmans, Grand Rapids, MI.

Stenschke, C., 2014, 'The presentation of Jesus in the missionary speeches of Acts and the mission of the church', Verbum et Ecclesia 35, Art. \#803, 18 pages. https://doi. org/10.4102/ve.v35i1.803

Stenschke, C., 2015, 'Recent contributions to the study of the reception of the Bible and their implications for Biblical studies in Africa', Religion and Theology 22(3-4), 329-383. https://doi.org/10.1163/15743012-02203002

Stenschke, C., 2018, 'The Jewish saviour for Israel in the missionary speeches of Acts', in A.W. White, C.A. Evans \& D. Wenham (eds.), Earliest perceptions of Jesus in context: Essays in honour of John Nolland on his 70th birthday, pp. 148-162, LiNTS 566 , Bloomsbury, London.

Steyn, G.J., 1995, Septuagint quotations in the context of the Petrine and Pauline speeches of the Acta Apostolorum, Contributions to Biblical Exegesis and Theology 12 , Kok Pharos, Kampen.

Sundkler, B. \& Steed, C., 2000, A history of the church in Africa, Cambridge University Press, Cambridge. 
Thyen, H., 2005, Das Johannesevangelium, HNT 6, Mohr Siebeck, Tübingen.

Treier, D.J., 2005, 'Typology', in K.J. Vanhoozer (ed.), Dictionary for theological interpretation of the Bible, pp. 823-827, Baker, Grand Rapids, MI.

Wenham, G.J., 1979, The book of Leviticus, NICOT, Eerdmans, Grand Rapids, MI.
Zehnle, R.F., 1971, Peter's Pentecost discourse: Tradition and Lukan reinterpretation in Peter's speeches of Acts 2 and 3, SBLMS 15, Abingdon, Nashville, TN.

Zimmermann, J., 1998, Messianische Texte aus Qumran: Königliche, priesterliche und prophetische Messiasvorstellungen in den Schriftrollen von Qumran, WUNT II.104, Mohr Siebeck, Tübingen. 